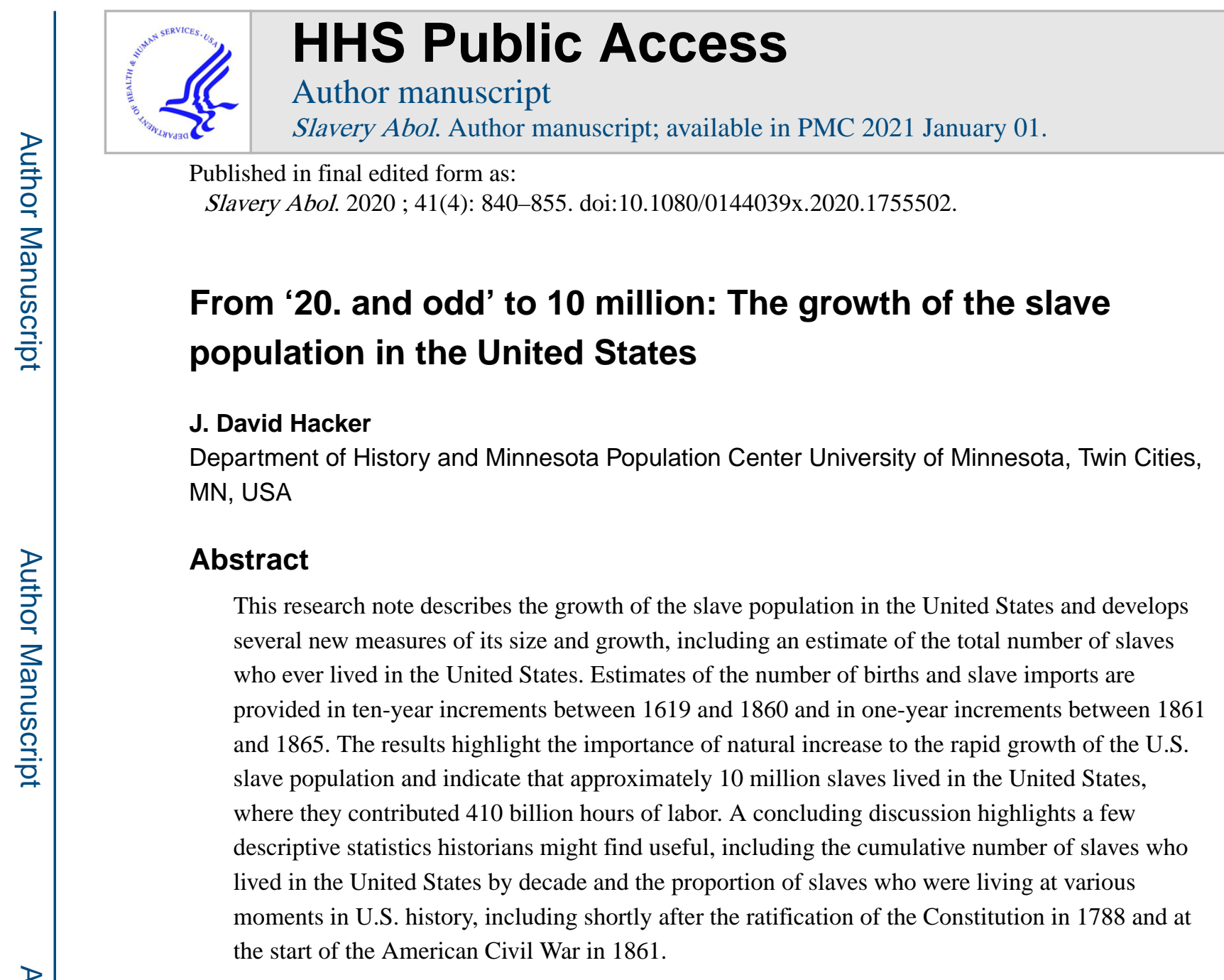

\title{
Keywords
}

Slavery; Demography; Population; Slave Trade; Slave fertility

\begin{abstract}
In August 1619, the English privateer White Lion brought a cargo of '20. and odd Negroes' captured from a Portuguese slave ship to Point Comfort, Virginia for sale, marking the conventional date of origin of African slavery in British North America. ${ }^{1}$ From that small beginning, the slave population grew rapidly. In 1790, the first census of the United States counted 697,624 slaves. In 1860, the eighth census counted 3,953,760. This remarkable growth was the result of two factors: (1) continued importation of new slaves from Africa and the Caribbean; and (2) natural population growth, especially among American-born slaves, who lived longer lives and bore more children than African-born slaves. Although slave imports accounted for most of the population growth in the seventeenth century and continued to be a significant factor until the federal government abolished the legal
\end{abstract}

\footnotetext{
hacke010@umn.edu.

${ }^{1}$ The origins of African slavery In British North America may have been earlier than the arrival of the White Lion. A census of Virginia in March 1619 counted 32 individuals of African descent. See William Thorndale, "The Virginia Census of 1619," Magazine of Virginia Genealogy, 33 (1995): 155-170; and John Thornton, 'The African Experience of the "20. and Odd Negroes" Arriving in Virginia in 1619', The William and Mary Quarterly, 55, no. 3 (1998): 421-434. The origins of African (and Indian) slavery are even earlier in parts of Spanish territory that eventually became part of the United States. A small number of African slaves lived in St. Augustine, Florida from the beginning of its settlement in 1565. Paul E. Hoffman, Florida's Frontiers (Bloomington, University of Indiana Press, 2002).
} 
importation of slaves in 1808, natural population growth was the more important of the two factors over the long run. The robust natural population growth of the slave population in the United States stands in dramatic contrast to negative rates of growth experienced by slave populations in the Caribbean and South America, which continued to grow only because of continued imports of slaves via the transatlantic slave trade. At the outbreak of the American Civil War in 1861, slaves in the United States comprised about 50 percent of the slaves living in the western hemisphere, despite the U.S. being the destination of less than 4 percent of slaves surviving the transatlantic Middle Passage. ${ }^{2}$

Demography is therefore central to our understanding of how and why slavery developed in the United States and how it differed from slavery elsewhere in the hemisphere. The growth of the slave population has important implications for comparative studies of slave wellbeing, disease environments, treatment, work regimes, and ability to form families. The relative contributions of the international slave trade and natural population growth to the slave population have important implications for the proportions of the slave population born in Africa or born locally and the development of slave culture. On-going debates about the contributions of slaves to the political foundations and economic growth of the United States depend in large part on the size of slave population, as do cost estimates for possible financial reparations to the descendants of former slaves. ${ }^{3}$

In 2019, USA Today published an on-line graphic feature charting the growth of the slave population in the United States to commemorate the 400th anniversary of the arrival of slaves in Virginia. ${ }^{4}$ I was consulted about the total number of slaves who had ever lived in the United States (including slaves who lived in English, French and Spanish territories that eventually became part of the United States). Although the number of slaves who lived in the United States is of obvious importance to our understanding of the institution's human cost and to the contribution of slave labor to the nation's growth and development, I was unable to find a published estimate and forced to construct my own. I did so by combining and harmonizing published estimates of the size of the slave population, slave birth rates, and slave imports, and supplementing those estimates when necessary with new estimates and a few reasoned guesses. Although based largely on published scholarship, the results of

2David Eltis, 'The U.S. Transatlantic Slave Trade, 1644-1867: An Assessment', Civil War History 54, no. 4 (2008): 347-378, and Stanley L. Engerman, Richard Sutch, and Gavin Wright, 'Slavery', in Historical Statistics of the United States, Earliest Times to the Present, Volume 2: Part B, Work and Welfare, eds. Susan B. Carter, Scott Sigmund Gartner, Michael R. Haines, Alan L. Olmstead, Richard Sutch, and Gavin Wright (Cambridge: Cambridge University Press, 2006), 369-374.

${ }^{3}$ Good summaries of slave demography in British North America and the United States include Lorena S. Walsh, 'African American Colonial Population', in A Population History of North America, eds. Michael R. Haines and Richard H. Steckel (Cambridge: Cambridge University Press, 2000), 191-239; Richard H. Steckel, 'The African American Population of the United States, 1790-1920', in A Population History of North America, eds. Michael R. Haines and Richard H. Steckel (Cambridge: Cambridge University Press, 2000), 433-481; John J. McCusker and Russell R. Menard, The Economy of British North America (Chapel Hill: University of North Carolina Press, 1991); and Michael R. Haines, 'The Population of the United States, 1790-1920', in The Cambridge Economic History of the United States, Volume II: The Long Nineteenth Century, eds. Stanley L. Engerman and Robert E. Gallman (Cambridge: Cambridge University Press, 2000), 143-205. On the recent debate on the impact of slavery on capitalism and economic growth in the United States, see Sven Beckert, Empire of Cotton: A Global History (New York: Vintage Books, 2014); Edward E. Baptist, The Half Has Never Been Told: Slavery and the Making of American Capitalism (New York, 2014); Alan L. Olmstead and Paul W. Rhode, 'Cotton, slavery, and the new history of capitalism', Explorations in Economic History 67 (2018): 1-17; and Gavin Wright, 'Slavery and Anglo-American capitalism revisited', Economic History Review (2020): 1-31. For a recent estimate of the present value of slave labor with regards to possible reparations, see Thomas Craemer, 'Estimating Slavery Reparations: Present Value Comparisons of Historical Multigenerational Reparations Policies', Social Science Quarterly 96, no. 2 (2015): 639-655.

${ }_{4}^{4}$ The graphic can be found at https://www.usatoday.com/pages/interactives/1619-african-slavery-history-maps-routes-interactivegraphic/?utm_campaign=s2seriesrecirc\&utm_content=news\&utm_medium=onsite\&utm_source=oembed. 
the exercise highlighted the relative contributions of births and imports to slave population growth in more detail and more comprehensively than has been provided elsewhere before. The results also yielded several new measures (e.g., the number of hours worked and personyears lived by slaves in each decade between 1630 and 1860) that should prove useful for historians.

This research note shows the results of my estimation procedures, together with other data and statistics implied by the series, including the number of slave births, slave imports, and the rate of natural increase in each decade 1620-1860. A few of the estimates (e.g., birth rates in the seventeenth century) are highly speculative. As discussed below, however, overall results and interpretations are robust to large potential errors in these values. ${ }^{5}$ It is my hope that publication of these results will highlight deficiencies in the existing data and stimulate new research. I outline each step in the estimation procedure, together with a brief description of the available source data, necessary assumptions, and potential errors. Despite some inconsistencies and a few unrealistic results in the seventeenth and early eighteenth centuries — when available data and published estimates are less reliable- the results indicate the emergence of rapid natural population growth in the slave population in the mid eighteenth century. I conclude that approximately 10 million slaves lived in the United States and that 40 percent of these slaves were living at the outbreak of the American Civil War in 1861. Between 1619 and 1865, slaves in the United States lived about 179 million personyears and contributed 410 billion hours of labor.

\section{Data, methods, and results}

All results are shown in Table 1. Columns 1 and 2 show the estimated number of slaves living at the start and end of each interval. These data come from two sources. For the colonial era, I relied on John McCusker's estimates of the size of black population published in the millennial edition of Historical Statistics of the United States, adjusted to account for the small percentage of the colonial black population estimated to have been free. ${ }^{6}$ For the period after the founding of the United States, I obtained information on the size of the slave and free black populations from the federal census, taken every 10 years beginning with the first census in 1790. I included small adjustments suggested by other researchers to account for the estimated number of slaves in territories not enumerated by the census (e.g., the number of slaves living in Texas prior to 1850$).{ }^{7}$ For the period 1861-65, I assumed the slave population continued to grow at the annual rate observed for the black population between

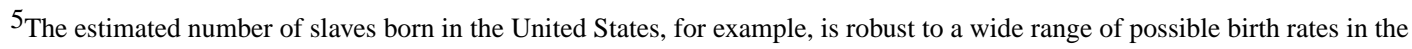
seventeenth century. Under most reasonable assumptions, less than 0.3 percent of all slave births occurred prior to 1700 .

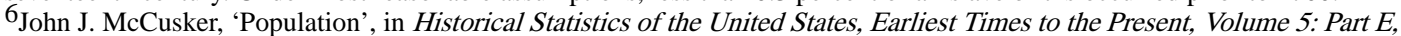
Governance and International Relations, eds. Susan B. Carter, Scott Sigmund Gartner, Michael R. Haines, Alan L. Olmstead, Richard Sutch, and Gavin Wright (Cambridge: Cambridge University Press, 2006), Series Eg41, 653. The size of the free black population was first measured for the nation in 1790, when it was 7.87 percent of the total black population. An early census count for Maryland recorded 4 percent of the colony's blacks as free in 1755, but the result is surely unrepresentative of other colonies with large numbers of slaves. I assumed that 2.0 percent of blacks between 1620 and 1770 were free, increasing to 4.93 percent in 1780 (halfway between the assumed 2.0 percent for 1770 and the 7.87 percent measured by the 1790 census). See Ira Berlin, Slaves Without Masters: The Free Negro in the Antebellum South (New York: Vintage Books, 1974), 3-4 for the Maryland estimates and comments on the low numbers of free blacks in the colonial period.

${ }^{7}$ Among other places, census counts can be found in Susan B. Carter, 'Slave Population,' in Historical Statistics of the United States, Earliest Times to the Present, Volume 2: Part B, Work and Welfare, eds. Susan B. Carter, Scott Sigmund Gartner, Michael R. Haines, Alan L. Olmstead, Richard Sutch, and Gavin Wright (Cambridge: Cambridge University Press): Table Bb1-98, 375- 379. For adjustments to the overall size of the black population for territories not covered by the census, see Peter D. McClelland and Richard J.
} 
the 1860 and 1870 censuses ( 0.94 percent), but was at the same time reduced by 500,000 emancipated slaves over the course of the war-either self-emancipated by running away or via the combined effects of the occupation of slave territory by Union forces and the Emancipation Proclamation. 8

The final series indicates that slave population growth was robust. Ten-year growth ratesshown in column 3-were very high in the seventeenth century, but from a small population base. Eighteenth-century growth rates for the slave population ranged from a high of 63.1 percent per decade in the 1730s to a low of 21.7 percent in the 1770s. The highest decennial growth rate in the nineteenth century was the 31.6 percent growth rate observed in the 1800-09, in part because of a large number of slaves imported immediately prior to Congress's prohibition of the international slave trade in 1808. After 1810, population growth rates ranged from a 10-year high of 30.4 percent in the 1820s to a low of 23.4 percent in the 1850s. Although population growth rates remained high throughout the antebellum period, growth was noticeably slower in the three decades after 1830 (averaging about 25 percent per decade) than in two decades before 1830 (averaging about 30 percent per decade).

Column 4, the number of person-years lived, is based on an assumption of constant population growth over each interval. A slave alive at the beginning of a decade and surviving to the end of the decade contributed 10 person-years, while a slave born exactly halfway into the interval and surviving to the end of the decade contributed 5 person-years. ${ }^{9}$ Column 5, the number of hours worked, is based on the assumption that the average age structure of the population in 1850 and 1860 was constant over time and that all slaves age 5-64 worked an average of 54 hours each week. ${ }^{10}$ In total, slaves in the United States worked an estimated 410 billion hours.

The number of slaves born in each interval, shown in column 7, is the result of first determining a best-estimate of the crude birth rate for the overall population (births per thousand person-years) and multiplying that estimate by the of number of person-years lived in the interval. The most reliable estimates of slave fertility are based on nineteenth-century census data. Despite some differences in methodological approaches and assumptions, all researchers have agreed that slave birth rates in the nineteenth century were very high, near a biological maximum for a human population. Melvin Zelnik used stable population methods to estimate a crude birth rate for the black population of "around 60" births per thousand

Zeckhauser, Demographic Dimensions of the New Republic: American Interregional Migration, Vital Statistics, and Manumissions, 1800-1860 (Cambridge: Cambridge University Press, 1982): 120.

${ }^{8}$ I assumed the first 375,000 of these emancipated slaves were evenly distributed between June 1, 1861 and May 30, 1864, with the final increment of 125,000 emancipations occurring between June 1, 1864 and April 9, 1865, consistent with research describing emancipation as a slow process encompassing the entire course of the war and estimates of the number of former slaves living in "contraband" camps or taking part in some form of federally-sponsored free labor in Union-occupied areas of the South in the spring of 1865. Ira Berlin, Barbara J. Fields, Steven F. Miller, Joseph P. Reidy, and Leslie S. Rowland, Slaves No More: Three Essays on Emancipation and the Civil War (Cambridge: University of Cambridge, 1992), 182-183.

${ }^{9}$ If $P_{\mathrm{t}}$ is equal to the size of the slave population on at the beginning of the decade and $P_{\mathrm{t}+10}$ equals the size of the slave population at the end of the decade, the number of person-years, assuming constant population growth $=\left(P_{\mathrm{t}+10}-P_{\mathrm{t}}\right) / \ln \left(\left(P_{\mathrm{t}+10} / P_{\mathrm{t}}\right) / 10\right)$.

${ }^{10}$ On average, 81.7 percent of the slave population in 1850 and 1860 was age 15-64. Over the censuses when the age structure can be observed (1820-1860), it appears to be relatively constant. For the typical slave workweek of 54 hours, see John F. Olson, 'Clock-Time vs. Real-Time: A Comparison of the Lengths of the Northern and the Southern Agricultural Work Years', in Without Consent or Contract: The Rise and Fall of American Slavery, Technical Papers, Vol. 1, eds. Robert W. Fogel and Stanley L. Engerman (New York: Norton, 1992), 216-240. The estimated millions of hours worked in each interval $=$ person-years lived $* 0.817 * 54 * 52 / 1,000,000$. 
population in 1830 and "about 54" in 1850. Reynolds Farley used slightly different methods to obtain an estimated birth rate of 53 in the 1840s and 49 in the 1850s. Jack Elben used stable population methods to calculate a crude birth rate of 53.1-53.2 births per thousand population between 1810 and 1830 . The estimated rate declined to 52.1 in the 1840 s and to 51.3 in the 1850s. McClelland and Zeckhauser, while concluding that crude birth rates were probably in the range of 50 to 55 births per thousand population in the antebellum period, created several series of estimates based on a range of different mortality and census undercount assumptions that generally were lower than the rates estimated by most other investigators. In their preferred series, the crude birth rate for the black population fell from 51.8 in 1810 to 44.2 in 1860 . In a more recent review of the population history of the nineteenth-century United States, Michael Haines cited a figure of 58.6 births per thousand population in the $1850 \mathrm{~s}$ and 55.0 in the $1860 \mathrm{~s}$. Thus, despite using somewhat different methods and assumptions, most researchers agree that birth rates for the black population were in the range of 50-60 births per thousand population in the early nineteenth century. All investigators estimated a modest decline in fertility of about 5-10 percent in the last two decades of the antebellum era, although there is no consensus on its causes. ${ }^{11}$

I found no published estimates of the crude birth rate for the slave population prior to 1800 . Colonial demographic historians agree, however, that moderate or high rates of natural population growth (above 1 percent) was not present until circa 1720 in the Chesapeake region and after 1760 in the lower South, strongly suggesting that slave fertility had increased from lower levels in the seventeenth century. Russell Menard's pioneering study of slave demography in Maryland charted the transition from a slave population that was not able to reproduce itself in 1653 to one experiencing robust natural population growth in 1730. Child-woman ratios in Maryland slave inventories analyzed by Menard approximately doubled between the 1660s and 1720s, suggesting a large increase in slave fertility rates, perhaps in combination with a decline in child mortality rates. ${ }^{12}$ Alan Kulikoff's study of slave inventories in Prince George's County, Maryland, which relied on a larger study population in the period from the 1720 s to the 1780 s, also documented a significant increase in child-woman ratios over time, although the increase was more modest than that observed for Menard for the earlier period (among slave women studied by Kulikoff, child-woman ratios increased about 40 percent over a span of 50 years). ${ }^{13}$ Similar trends in other parts of

\footnotetext{
${ }^{11}$ Melvin Zelnik, 'Fertility of the American Negro in 1830 and 1850', Population Studies 20, no. 1 (1966): 77-83; Reynolds Farley, Growth of the Black Population: A Study of Demographic Trends (Chicago: Markham Publishing Company, 1970); Jack Ericson Eblen, 'New Estimates of the Vital Rates of the United States Black Population during the Nineteenth Century', Demography 11, no. 2 (1974): 301-319; Peter D. McClelland and Richard J. Zeckhauser, Demographic Dimensions of the New Republic: American Interregional Migration, Vital Statistics, and Manumissions, 1800-1860(Cambridge: Cambridge University Press, 1982), Series D23, 184; Michael R. Haines, 'The Population of the United States, 1790-1920', in The Cambridge Economic History of the United States, Volume II: The Long Nineteenth Century, eds. Stanley L. Engerman and Robert E. Gallman (Cambridge: Cambridge University Press, 2000), 158. All crude birth rate estimates cited above are for the black population, not the slave population. Given that the free black population was, at its largest, just over 10 percent of the black population, fertility differences would have to be very large before biasing the overall results. Stable population estimates are based in part on an assumed mortality schedule or life table. Until recently, the only available life table was Paul H. Jacobson's 1850 life table for Massachusetts and Maryland, which was based on relatively few slave decedents. If Richard Steckel is correct that age pattern of slave mortality did not conform to the age pattern of white mortality - compared to the white population, slave infant and child mortality rates were elevated relative to adult slave mortality rates - birth rates derived using stable population methods and Jacobson's life table may be too low. Given that the estimated nineteenthcentury birth rates are already near 60 births per thousand, however, it is difficult to see how much higher slave birth rates could have been. Richard H. Steckel, 'Birth Weights and Infant Mortality among American Slaves', Explorations in Economic History 23, no. 2 (1986): 173-198.

${ }^{12}$ Russell R. Menard, 'The Maryland Slave Population, 1658 to 1730: A Demographic Profile of Blacks in Four Counties', The William and Mary Quarterly 32, no. 1 (1975), 29-54.
} 
the Chesapeake and in the lower South were documented by other researchers and were recently synthesized by Philip D. Morgan. Although researchers have been unable to demonstrate causal relationships, the increases observed in slave fertility are consistent with the emergence of American-born majority slave populations, more balanced slave sex ratios, improvements in slave health, increases in average slave holding sizes, and increased slave population densities, all of which facilitated slave marriages (although not legally recognized as such) and childbearing. ${ }^{14}$

Given this review of the published literature, what is the best estimate for slave fertility in each decade? For the period after 1800, I took the average of the highest published estimate for the period ( 60 births per thousand) and the lowest estimate in each decade from McClelland and Zeckhauser. The assumed birth rate averaged 55.1 births per thousand in the antebellum period, a plausible level given similar estimated birth rates in the southern white population and the added pressures and incentives to bear more children imposed on slave women by owners. ${ }^{15}$ Prior to 1800 , I worked backwards from the nineteenth-century estimates using trends in child-woman ratios documented by Morgan from multiple studies. ${ }^{16}$ The exercise suggested that birth rates were below 30 in the seventeenth century, increased to above 40 births after 1720 and reached 50 births per thousand before the end of the century. Given high rates of slave mortality (probably in the range of 30 to 40 deaths per thousand population or higher), birth rates below 30 would not sustain the size of the slave population without additional imports, consistent with what is known about negative to low rates on natural population growth in the seventeenth century. ${ }^{17}$ All birth rate assumptions are shown in column 6 and the corresponding number of births associated with the rate in each interval in column 7. The resulting estimates indicate that between 1620 and 1865 over 9.3 million slaves were born in the United States or territory that became part of the United States. Among these births, 5.6 million (60 percent) occurred after 1830.

I estimated the number of slaves imported in each decade using the Transatlantic and IntraAmerican slave trade databases. I relied on the 2010 estimates file constructed by David Eltis and Paul F. Lachance, which incorporates year-to-year adjustments for slave disembarkations believed to be missing from the historical record (about 15 percent overall disembarkations). For the Intra-American slave trade, I relied on the published estimates

\footnotetext{
${ }^{13}$ Allan Kulikoff, 'A “Prolifick” People: Black Population Growth in the Chesapeake Colonies, 1700-1790', Southern Studies 16, no. 4 (1977), 391-428.

${ }^{14}$ Philip D. Morgan, Slave Counterpoint: Black Culture in the Eighteeenth-Century Cheseapeake and Lowcountry (Chapel Hill: Omohundro Institute of Early American History and Culture, Williamsburg, Virginia, by the University of North Carolina Press, 1998), 79-95.

${ }^{15}$ On slave owner pressures and incentives for childbearing, see Marie Jenkins Schwartz, Born in Bondage: Growing Up Enslaved in the Antebellum South (Cambridge, MA: Harvard University Press, 2000), 191.

16 I used estimated regional slave populations estimated by McCusker and Menard to weight the regional child-woman ratios synthesized by Morgan. McCusker and Menard, The Economy of British North America. Morgan, Slave Counterpoint, 83 . The 1850 census tabulated the number of slave children in sufficiently detailed age categories to create a similar ratio of slave children age 0-14 to slave mothers age 15-44 used by the colonial historians. Although trends in child-woman ratios are typically dominated by changes in fertility rather than changes in child mortality, Menard concluded that "both were probably at work" in the seventeenth and early eighteenth century. I assumed that two-thirds of the trend in child-woman ratios observed by prior to 1730 was the result of trends in slave fertility and one-third was the result of trends in child mortality and that trends in child-woman ratios in the eighteenth century accurately reflected trends in the birth rate.

${ }^{17}$ See also, Herbert S. Klein and Stanley L. Engerman, 'Fertility Differentials between Slaves in the United States and the British West Indies: A Note on Lactation Practices and Their Possible Implications', The William and Mary Quarterly 35, no. 2 (1978), 357-354 and Philip D. Morgan and Michael L. Nicholls, 'Slaves in Piedmont Virginia, 1720-1790', The William and Mary Quarterly 46, no. 2 (1989),211-251.
} 
recently made by Gregory O'Malley. The two sets of estimates are combined and shown in column $8 .{ }^{18}$

Among the 460,366 slave imports documented by the combined slave trade databases, 6,121 slaves were smuggled into the United States after the probation of the international slave trade in 1808. It is likely that an additional but unknown number of smuggled slaves escaped documentation. To estimate the number of slaves not recorded in the databases, I constructed a new estimate using the new complete-count IPUMS dataset of the 1870 census. ${ }^{19}$ Among the 4.8 million blacks enumerated by the census, 1,984 (0.04\%) reported an African birthplace. Of these, however, 1,031 were over the age of 70, suggesting the strong possibility that their arrival in the United States occurred before the slave trade was abolished in 1808. A few others black individuals in the 1870 census with an African birthplace were under the age of 10 and were unlikely to have been smuggled during the war. ${ }^{20}$ To determine the number of slaves smuggled in each decade prior to 1860 , I took all individuals age 10-70 who reported an African birthplace, imputed an expected age at importation (and corresponding date) using data for slaves on captured vessels, "reversesurvived" the population to determine the number of smuggled slaves at the arrival date, and summed the total for each decade. In the decades where my estimate exceeded the number of smuggled slaves documented in the database, I included the additional number is column 9 , rounded to the nearest hundred. The result indicated lower numbers than occasionally assumed in the literature: less than 10,000 smuggled slaves over the entire antebellum period, compared to the 50,000 or more typically assumed. ${ }^{21}$ Assuming the slave imports documented in the slave trade database and these estimates of slave smuggling are correct, 463,066 slaves arrived in the United States from Africa or via the Intra-American slave trade. This total is less than one-eighth of the total number of slaves currently living at the start of the Civil War, a simple but vivid illustration of the importance of natural population growth to the growth of the U.S. slave population.

If we assume low to negligible out-migration from the slave population, the rate of natural increase can be estimated by subtracting the total number of imported and smuggled slaves in the decade from the size of the population increase. Column 10 shows the rate of natural increase per hundred person-years lived. ${ }^{22}$ Results are erratic in the decades prior to 1750 ,

\footnotetext{
18 A description of the Transatlantic Slave Trade Database can be found in David Eltis and David Richardson, 'A New Assessment of the Transatlantic Slave Trade', inExtending the Frontiers: Essays of the New Transatlantic Slave Trade Database, eds. David Eltis and David Richardson (New Haven: Yale University Press), 1-60. Details on the 2010 estimates made by Eltis and Lachance can be found in David Eltis and Paul F. Lachance, 'Estimates of the Size and Direction of the Transatlantic Slave Trade,” (2009), available at https:// slavevoyages.org/documents/download/2010estimates-method.pdf. For the Intra-American slave trade and the published estimate of the number of slaves in each decade, see Gregory E. O'Malley, Final Passages: The Intercolonial Slave Trade of British America, 1619-1807 (Chapel Hill: Omohundro Institute of Early American History and Culture, Williamsburg, Virginia, by the University of North Carolina Press, 2014), 351-381.

${ }^{19}$ Steven Ruggles, Sarah Flood, Ronald Goeken, Josiah Grover, Erin Meyer, Jose Pacas and Matthew Sobek. IPUMS USA: Version 9.0 [dataset]. Minneapolis, MN: IPUMS, 2019. https://doi.org/10.18128/D010.V9.0.

${ }^{20}$ In 1860, the schooner Clotilda arrived in Mobile Bay with approximately 110 smuggled African slaves on board, the last known smuggled slaves to the U.S. Sylviane A. Diouf, Dreams of Africa in Alabama: The Slave Ship Clotilda and the Story of the Last Africans Brought to America (New York: Oxford University Press, 2007).

${ }^{21}$ For the age distribution of slaves on captured vessels and estimates of slave smuggling, see McClelland and Zeckhauser,

Demographic Dimensions, 48, 123. I assumed 50 percent of smuggled slaves died within 10 years of their arrival in the U.S. and that slaves who survived the first 10 years subsequently experienced mortality conditions equivalent to a Model West life table with life expectancy at age 35 of 24.6 years, a level suggested by application of the two-census mortality estimation method of the black population enumerated in the 1850 and 1860 censuses. See McClelland and Zeckhauser, Demographic Dimensions, 123 for the wide range of slave smuggling estimates.
} 
reflecting poor estimates of population growth or slave imports in the seventeenth and early eighteenth centuries. After 1800, the rate of natural increase averaged 2.5 per hundred person-years lived. Given this rate, the slave population doubled in size by natural means every 28 years. Although the results appear unreliable in individual decades before 1750, a long-term increase in the rate of natural increase is evident. Figure 1 plots a moving average of the rate of natural increase between 1660 and 1860, with more averaging in earlier decades. ${ }^{23}$ The figure indicates that natural increase was negative or below one percent in decades before 1750 , after which the rate climbed to a peak of 2.9 percent in the $1820 \mathrm{~s}$ before declining to 2.2 percent in the final decade.

The original goal of this project was to construct an estimate of the number of slaves who lived in the United States. Doing so is a simple matter of adding all slave births and imports together for each interval and summing the results. Column 11 shows the subtotals for each decade. The overall total indicates that the estimated number of slaves who lived in the United States was just under 10 million. Column 12 shows the percentage of all slaves who were born or imported in each decade. For example, nearly 1-in-5 (19.0 percent) of all slaves who ever lived in the United States were born or imported in the 1850s. Column 13 shows the cumulative number of slaves who lived up to and including the current decade, while column 14 shows the cumulative percentage. The results for the decade 1790-1800, for example, indicates that 1.75 million slaves had been born or imported prior to 1800 , representing less than one-fifth of the number of slaves who ever lived in the United States. Stated another way, about 4 out of 5 slaves who ever lived in the United States were born or imported in the nineteenth century.

How accurate are these numbers? As discussed earlier, results for the seventeenth and early eighteenth centuries are subject to greater error. Given the large proportion of all slaves who were born or imported after 1750, however, estimates of the number of slaves who lived in the United States are robust to significant errors before 1750. The most important assumption is the estimated slave birth rate in each decade. If we use the lowest and highest estimated birth rates made by researchers in the nineteenth century, and further assume that the birth rate estimates shown prior to 1800 in column 6 are 10 births per thousand too high or too low-the estimated number of slave births varies about plus or minus 10 percent. Although the highest and lowest estimated rates are less probable, the true number of slaves born in the United States may have been as low as 8.4 million or as high as 10.3 million.

In one important respect, the number of slaves estimated in Table 1 is conservative: no consideration was made for the probable undercount of the slaves in the U.S. census. Historians have often commented on the immense challenge of conducting a nation-wide census given the tremendous geographic size of the nation, a rapidly growing and moving

\footnotetext{
${ }^{22}$ Beyond a few thousand former slaves who found their way to Canada after the Revolution and in the 1840s and 1850s, there were likely few out-migrants from the U.S. slave population that escaped measurement in Table 1. Fugitives who successfully escaped slavery and slaves who were manumitted by their owners or who purchased their own freedom and lived in the United States, however, are "out-migrants" from the slave population in a figurative sense and were likely significant enough in number to bias the natural increase rate. For the period 1800-1860, I relied on McClelland and Zeckhauser's estimates of "manumissions" to adjust the estimated natural increase rate. McCelland and Zeckhauser, Demographic Dimensions, 19. For the period 1770-1800, I made similar estimates, rounded to the nearest 5,000, and assumed the level of manumissions and fugitives was negligible in all previous decades.

${ }^{23}$ For each decade before 1750 , I averaged the rate of natural increase for the current decade, the two prior decades, and the two following decades. For decades between 1750 and 1800, I averaged the prior, current, and following decades.
} 
population spread in low densities across the land, and the relative primitive condition of transportation and technology in the early nineteenth century. Although there are no good estimates of the census undercount of the slave or free black populations, a recent published study of the undercount for the white population in 1850 and 1860 censuses indicated that the southern white population suffered a 6.6 net undercount in the 1850 census, a 7.6 percent net undercount in the 1860 census, and an 8.8 percent undercount in the 1870 census. ${ }^{24}$ If we assumed similar levels of undercounts of the slave population, the total number of slaves who ever lived in the United States would be about 10.5 million.

\section{Discussion}

The results of this data gathering and harmonization exercise dramatically illustrates the rapid growth of race slavery in the United States. Although poor quality data results in some inconsistencies and erratic results prior to 1750 , the rapid growth of the slave population and the importance of natural increase to that growth are clear. In 1700, eighty years after the arrival of the first slaves in Virginia, less than 35,000 slaves were currently living in or had lived and died in the territory that would become the United States. Eighty years later, as the United States was fighting for its independence from Great Britain, the total number of slaves who had lived in the U.S. exceeded one million. And eighty years after that, 10 months prior to the beginning of the Civil War that would ultimately result in the destruction of slavery, 8.9 million slaves had lived in the U.S. This exponential growth is dramatically illustrated in Figure 2, which charts the cumulative number of slaves who lived in the United States and the number currently living in each year. Remarkably, in the five years between the 1860 census and the end of the war in 1865, another 927,371 slaves were born, adding to the dreadful tally and increasing the total number of slaves who lived in the United States to almost 10 million.

The percentage, cumulative number, and cumulative percentage of slaves in each decade also reflects this rapid growth, but offers slightly different perspectives, especially when combined with the number of slaves currently living, born, and imported. In 1790, for example, two years after the ratification of the Constitution, the number of currently living slaves $(706,514)$ represented just 7.2 percent of the slaves who would subsequently live in the United States, underscoring the national tragedy of failing to find a compromise to end the institution. Among other possible uses, the percentage column can be used to highlight the fact that more than 8-in-10 slaves (82.1 percent) who lived in the United States were born or imported in the nineteenth century. Although historians often stress the need to move beyond the traditional view of American slavery as an antebellum institution, it was a nineteenth-century institution that a large majority of slaves experienced. Finally, the results also allow comparisons of the currently living slave population to the total number of slaves who ever lived or who had lived up to different years. In 1861, for example, at the outbreak of the Civil War, 40.7 percent of slaves who ever lived in the Unites States were currently living. Thus, more than 4-in-10 slaves who lived in the United States witnessed or participated in the struggle for freedom.

${ }^{24}$ J. David Hacker, 'New Estimates of Census Coverage in the United States, 1850-1930', Social Science History 37, no. 1 (2013): 71-101. 


\section{Acknowledgments}

The author would like to thank Adam Rothman and USA Today graphic editor James Sergent for suggesting this study, Clifton Berry at the Unpaid Labor Project for encouragement, Amy Murrell Taylor, Alex Borucki, David Eltis and Gregory O'Malley for assistance, and Saje Mathieu for comments. This paper was supported in part by funding from the Minnesota Population Center (P2C HD041023) and through a grant from the Eunice Kennedy Shriver National Institute for Child Health and Human Development (R01-HD082120-01). 


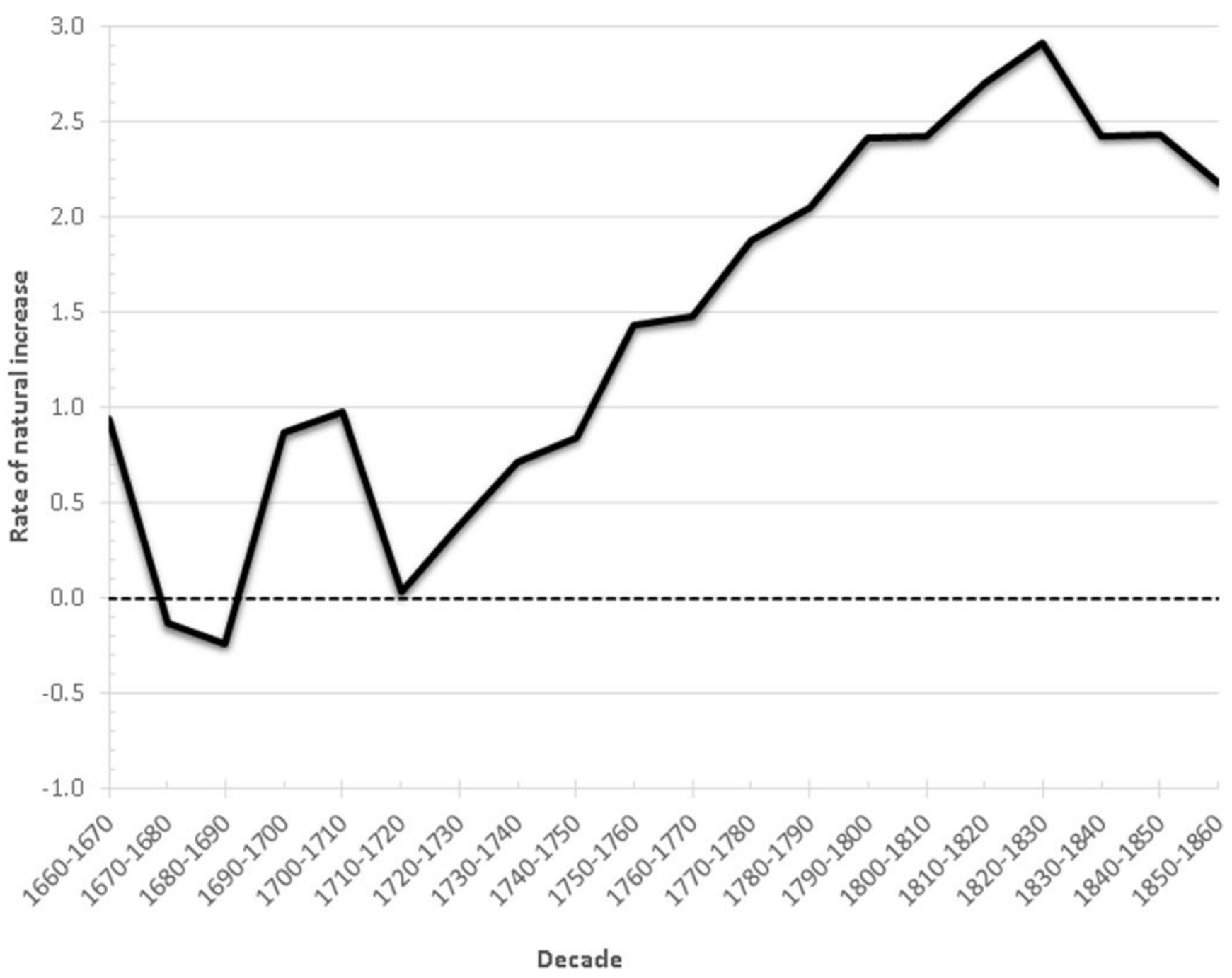

Figure 1.

Rate of natural increase by decade, slave population of the United States, 1660-1860

Source: Moving average of rates in Table 1 column 10. 

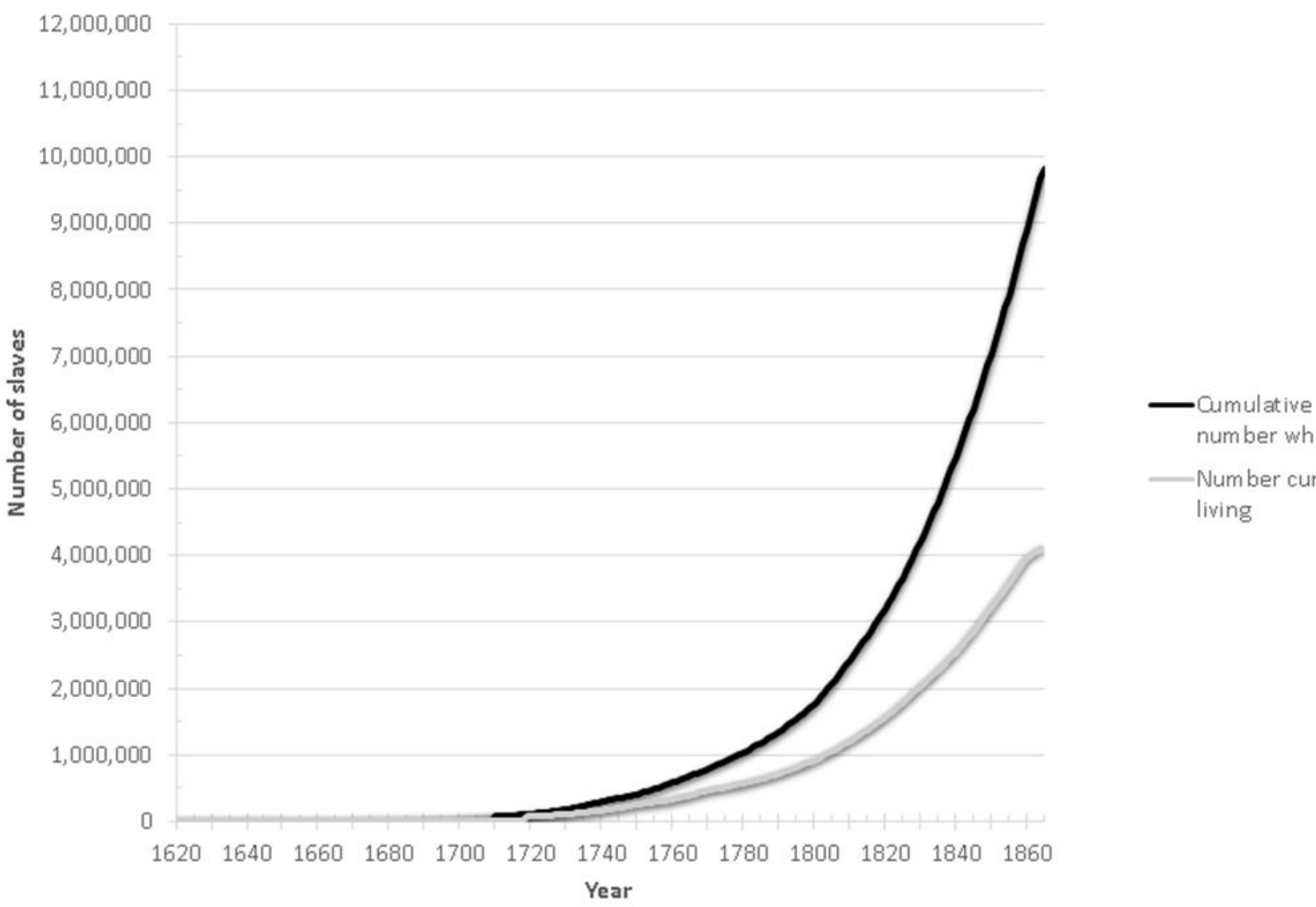
number wholived

Figure 2.

Number of slaves in the United States by year

Source: Table 1 columns 12 and 14. 


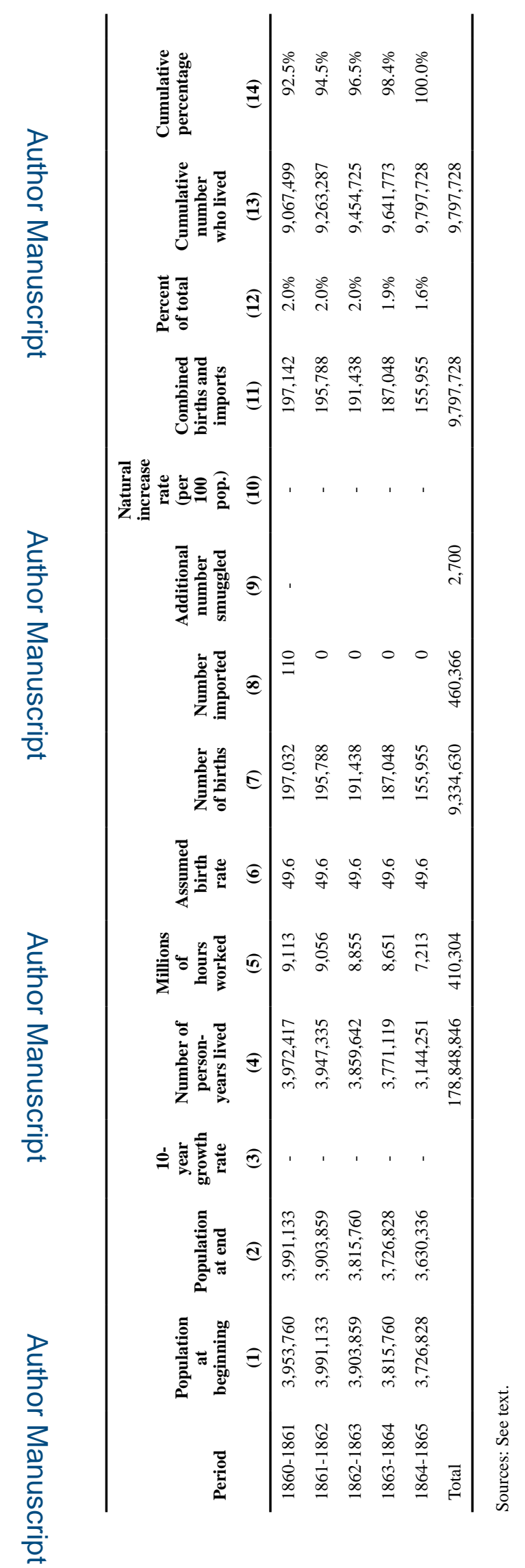

Slavery Abol. Author manuscript; available in PMC 2021 January 01. 